\title{
ZALECENIA I ZACHĘTY DO ŻYCIA DOSKONALEGO W KORESPONDENCJI GRZEGORZA Z NAZJANZU
}

Korespondencja Grzegorza z Nazjanzu († 390) to zbiór 244, w przeważającej części stosunkowo krótkich listów ${ }^{1}$. Ich styl ukazuje walory pisarskie autora, a także umiejętność zamknięcia w kilku zdaniach istoty przekazywanej idei. Listy Grzegorza były częstym przedmiotem badań podejmowanych z różnych perspektyw merytorycznych. Badano je bowiem analizując zastosowane cytaty ze sztuk teatralnych ${ }^{2}$, rozpatrując treści konsolacyjne ${ }^{3}$, wnikając w prośby o charakterze rekomendacji lub protekcji ${ }^{4}$ czy też zajmując się jego postawą względem siebie i otoczenia ${ }^{5}$. Tak wielostronny wachlarz tematyczny pokazuje, że listy Grzegorza zawierają bardzo wiele informacji autobiograficznych, na podstawie których można odtworzyć niektóre wydarzenia z jego życia w sposób dosyć dokładny ${ }^{6}$.

Tekst niniejszego artykułu podejmuje kolejny aspekt twórczości epistolograficznej Nazjanzeńczyka, którym jest jego troska o doskonałość życia chrześcijańskiego monitowana przez niego w postaci różnego rodzaju zaleceń i zachęt. Analizie zostały poddane listy pisane po powrocie Grzegorza z Konstantynopola do Kapadocji, a więc począwszy od listu 88. Rozpoczęła się wówczas ostatnia

\footnotetext{
${ }^{*}$ Ks. prof. dr hab. Norbert Widok - profesor nadzwyczajny w Katedrze Historii Kościoła i Patrologii na Wydziale Teologicznym Uniwersytetu Opolskiego; e-mail: nwidok@uni.opole.pl.

${ }^{1}$ Szczegółowe informacje dotyczące listów Grzegorza z Nazjanzu zob. Quasten III 249-251.

${ }^{2}$ Por. C.U. Crimi, Allusioni e citatzioni di testi teatrali nell Epistolario di Gregorio Nazianzeno, Catania 1981.

${ }^{3}$ Por. J.F. Mitchell, Consolatory lettres in Basil and Gregory Nazianzen, „Hermes” 96 (1968) 299-318; L. Małunowiczówna, Listy konsolacyjne i mowy żałobne Grzegorza z Nazjanzu, RTK 25 (1978) z. 4, 173-201; B. Amata, „Decor”, , mediocritas”, ,, consolatio” nelle lettere di S. Gregorio Nazianzeno, w: Culture e Lingue Classiche 3. Terzo Convegno di aggiornamento e didattica, ed. B. Amata, Roma 1993, 965-985.

${ }^{4}$ Por. P. Gallay, Saint Grégoire de Nazianze dans sa correspondance, „Bulletin des Facultés Catholiques de Lyon” 43 (1967) 5-25; N. Widok, Postawa Grzegorza z Nazjanzu wobec świeckich w świetle jego listów protekcyjnych, VoxP 22 (2002) t. 42-43, 187-207.

${ }^{5}$ Por. N. Widok, Refleksje o sobie samym w korespondencji starego Grzegorza z Nazjanzu, VoxP 31 (2011) t. 56, 349-370; tenże, Troska o sprawy Kościoła w korespondencji ostatniej dekady życia Grzegorza z Nazjanzu, VoxP 36 (2016) t. 65, 697-716.

${ }^{6} \mathrm{Na}$ takiej zasadzie badawczej powstała rozprawa doktorska, której autorem jest S. Barresi, $L a$ vita e l'opera di Gregorio di Nazianzeno attraverso l'epistolario, Catania 1955.
} 
dekada życia Grzegorza, która charakteryzowała się aktywnością przez słowo pisane raczej aniżeli poprzez mówione. Nie będąc w sposób bezpośredni odpowiedzialny za lokalną wspólnotę z mianowania wyższej instancji, zajął się głoszeniem zasad chrześcijańskich m.in. poprzez kontakty listowne z wieloma osobami. Poczuwał się do takiego obowiązku z racji swego wieku, doświadczenia życiowego i przede wszystkim pasterskiej odpowiedzialności. Zatroskanie zatem Grzegorza o wysoką jakość życia duchowego obejmowało zarówno osoby duchowne i mnichów, jak i ludzi świeckich, oraz członków rodziny.

1. Wobec duchownych i mnichów. Po ustąpieniu ze stolicy biskupiej w Konstantynopolu Grzegorz baczną uwagę zwracał na działalność duchownych, zwłaszcza jemu bliskich, z którymi współpracował w stolicy. Ważną dla niego osobistością był bez wątpienia jego następca - Nektariusz. Do niego w duchu życzliwości i pokoju Nazjanzeńczyk zwraca się słowami:

„Ale i mozoły ze swej strony z przyjacielem podejmuj, byś ze wszech miar był sprawiedliwy, sprawiedliwie i słusznie zażywając przyjaźni i przyjaciół. I niech ci szczęście długo służy, byś dużo dobrego czynił"”.

Akcent w tej wypowiedzi został położony na trwanie w obopólnej przyjaźni, polegającej na dzieleniu się ze swoim poprzednikiem pasterskimi problemami. Grzegorz bowiem uważa, że jego następca powinien tak właśnie czynić, skoro mu podpowiada, aby „słusznie zażywał przyjaźni i przyjaciół”. Tym sposobem Grzegorz wyraził także swoje pragnienie utrzymywania przyjaznych stosunków ze współbratem w biskupstwie. W tej atmosferze życzliwości i wzajemnej ufności Grzegorz ośmielił się podkreślić cechę, którą Nektariusz powinien się odznaczać, a jest nią sprawiedliwość, której powinien przestrzegać ,ze wszech miar”, czyli przy każdej sposobności jego biskupiej aktywności. Tą cechą ma też się kierować we wspomnianej przyjacielskiej relacji. Dla Grzegorza sprawiedliwość jest zatem podstawą działania, a następstwem tego staje się szczęście, które jest źródłem wszelakiego dobra.

Bezpośrednią kontynuacją powyższej wypowiedzi są słowa kolejnego listu adresowanego do Nektariusza. Obok kilku życzliwości skierowanych do niego Grzegorz nawiązuje do stanu, jaki obaj reprezentują, domagając się zaufania. Ujął swe pragnienie w następujący sposób:

„Abyśmy zaś sobie wzajem dali dowód zaufania i jako słudzy Boży jakimś ludzkim nie ulegli uczuciom - przedkładam ci następującą prośbę, a ty przychyl się życzliwie"s.

Kapadocki pasterz na równi stawia siebie i adresata co do wymogu wzajemnego zaufania, które jest konsekwencją trwania w przyjaźni. Odwołuje się

${ }^{7}$ Gregorius Nazianzenus, Epistula 88 [Nectario], PG 37, 164A, thum J. Stahr: Grzegorz z Nazjanzu, Listy, POK 15, Poznań 1933 [reprint 2005], 120.

${ }^{8}$ Tenże, Epistula 91 [Nectario], PG 37, 165B, POK 15, 122. 
ponadto do piastowanego przez nich stanowiska, nazywając siebie i swego adresata „sługami Bożymi”. Świadomość tego faktu nie może doprowadzić do uległości - jak to nazwał Grzegorz - „ludzkim uczuciom”, wynikającym z upadłej ludzkiej natury. Warto zauważyć obecne w tej wypowiedzi przeciwstawne sformułowania: „słudzy Boży” oraz „ludzkie uczucia” jako wyrażenia ukazujące dwa przeciwstawne bieguny duchowej kondycji. Tak nakreślony poziom doskonałości adresata był ważny dla Grzegorza z tego powodu, aby wyrazić wstawienniczą prośbę za Pankracjusza, będącego kimś bliskim dla niego.

Doskonałym pomysłem dla podtrzymania doskonałości, a nawet powiększenia jej, jest podarunek w postaci książki, którą Grzegorz przekazał biskupowi Tyany, Teodorowi. Temu podarkowi towarzyszyła taka motywacja:
„Abyś jednak miał także pamiątkę ode mnie, a zarazem od świętego Bazylego, posyłam ci książkę Orygenesa, Filokalję, zawierający wybór rzeczy poży- tecznych dla uczonego. Racz ją przyjąć i zdać sprawę z korzyści czytania: wszak wspiera cię i zapał i Duch"".

List przeniknięty jest życzliwością dla brata w biskupstwie podkreślającąjego uczoność. Upominek w postaci książki ma pomnożyć wiedzę adresata, czego też Grzegorz oczekuje w postaci „korzyści z czytania”. Ponadto zdaje sobie sprawę z pobożności, jaką odznacza się Teodor, skoro zauważa, że towarzyszy mu zapał i Duch. Z jednej strony Nazjanzeńczyk cieszy się z cnót posiadanych przez Teodora, z drugiej jednak pragnie dla niego jeszcze czegoś więcej, nie poprzestając na tym tylko, co już ma. Przy okazji, jakby mimochodem, zachęca do uznania wielkości innych teologów, jak Orygenes i Bazyli.

Nieco później Teodor był odbiorcą innego listu, w którym Grzegorz prosi o pomoc dla synów Nikobula. Nie zapomina o wielkoduszności adresata i dodaje: „Chciałbym, żeby ich charaktery zaprawiały się do cnoty przez ciągłą styczność z twą doskonałością"10. Podobnie jak w poprzednim liście, tak i w obecnym Nazjanzeńczyk podkreśla zalety biskupa Tyany i zakłada, że wartości duchowe, którymi się wyróżnia, są na tyle skuteczne, by wpłynęły także na rozwój duchowy polecanych przyszłych wychowanków. Grzegorz tym sposobem postawił przed Teodorem pedagogiczne zadanie do wykonania: wychować dzieci przez pryzmat własnej osoby, nic jednocześnie nie uszczuplając ze swego duchowego wizerunku.

Teodor, biskup Tyany, w krótkim odstępie czasu otrzymał kolejnych pięć listów, które odnosiły się za każdym razem do tej samej kwestii, a mianowicie polecania adresatowi różnych osób, które były w potrzebie egzystencjalnej i wymagały jego opieki ${ }^{11}$. Grzegorz podkreśla duchowe zalety Teodora, które nie pozwola, aby działa się niesprawiedliwość wobec powierzonych mu osób,

\footnotetext{
${ }^{9}$ Tenże, Epistula 115 [Theodoro], PG 37, 212C, POK 15, 160.

${ }^{10}$ Tenże, Epistula 157 [Theodoro], PG 37, 265A. POK 15, 201.

${ }^{11}$ Są to następujące listy: 159 [Theodoro], 160 [Theodoro], 161 [Theodoro], 162 [Theodoro], 163 [Theodoro].
} 
ponieważ był opiekuńczy, sprawiedliwy w rozsądzaniu, pomocny w modlitwach, a nawet był „wielkim lekarzem dusz”. Trzeba przyznać, że Grzegorz wymagał od swego zwierzchnika, tj. metropolity Kapadocji Drugiej ${ }^{12}$, duchowego heroizmu, by każdą kwestię doprowadzić do końca według założeń autora tych listów.

Helladiusz to biskup Cezarei, do którego Grzegorz kieruje list, polecając Nikobula. Zwraca się do niego z bardzo śmiałymi słowami: „Winieneś mi zaś - niech to nie brzmi przykro - pomoc w rzeczach duchownych jako biskup biskupowi"13. Ten krótki fragment listu zawiera ważną informację dotyczącą pola działania Grzegorza, które obejmuje „rzeczy duchowne”. Biskup zatem z wielką świadomością wypowiada się na temat celów i zamierzeń formułowanych na kartach swych listów.

Inny biskup, także o imieniu Helladiusz, miał na prośbę Grzegorza zabiegać o sprawiedliwe potraktowanie swego prezbitera, Sacerdosa. Nieco dłuższy list, wyjawiający różne relacje osobowe i opis petycji, kończy się wyraźną prośbą:

„Nie wyjawiaj też urazy, którą lepiej ukrywać, niż uzewnętrzniać, żebyś go nauczył i innych zalet i wyrozumiałości tym swoim przykładem"14.

Prośba kierowana do adresata jest właściwie bezpośrednim nakazem do wykonania pewnych czynności. Dotyczą one sfery duchowej, a właściwie relacji międzyludzkich, których podstawą są posiadane zalety. Biskup podaje, co odbiorca listu powinien uczynić. Proponuje ukryć urazy, czyli stać się łagodnym, aby taki przykład skłaniał owego prezbitera do nabycia różnych zalet, głównie przyjęcia postawy wyrozumiałości. Grzegorz przedstawił potencjalny wzorzec działania biskupa Helladiusza, zanim przystapi do wypełniania prośby Nazjanzeńczyka.

Obok biskupów, do których Grzegorz słał listy, byli też prezbiterzy. Jednym z nich był wzmiankowany już wyżej Sacerdos, powierzany jednemu z biskupów. Gdy zarządzał przytułkiem dla biednych i klasztorem, został oczerniony i rozpoczęła się wielokierunkowa korespondencja wokół jego osoby. Również Grzegorz napisał do niego kilka listów. W jednym z nich stwierdza:

„Co jest najpierwsze wśród rzeczy pięknych, chyba wiesz: jest to zawsze Boga posiadać i stać się Boga nabytkiem przez zażyłość z Nim i wstępowanie ku Niemu"15.

Sytuacja Sacerdosa była skomplikowana, gdyż nie obyło się bez częstego stawania przed sądami. Grzegorz pospieszył mu z pomoca, oferując swoje wstawiennictwo u znanych mu urzędników. W obecnym liście biskup przenosi

${ }^{12}$ Cesarz Walens w 372 r. podzielił Kapadocję na dwie prowincje: jedną ze stolicą w Cezarei, a drugą ze stolicą w Podandos, a potem na prośbę biskupa Antyma, w Tyanie; por. J.M. Szymusiak, Grzegorz Teolog. U źródet chrześcijańskiej myśli IV wieku, Poznań 1965, 142-143.

${ }^{13}$ Gregorius Nazianzenus, Epistula 167 [Helladio], PG 37, 277B, POK 15, 209.

${ }^{14}$ Tenże, Epistula 219 [Helladio], PG 37, 360A, POK 15, 267.

${ }^{15}$ Tenże, Epistula 212 [Sacerdoti], PG 37, 349A, POK 15, 260. 
ciężar sprawy na forum duchowe, przypominając Sacerdosowi to, co powinno być najważniejsze w życiu kapłańskim - „Boga posiadać i stać się Boga nabytkiem". Tym sposobem biskup wstępnie podzielił się z prezbiterem swoim doświadczeniem, kiedy podobnie został oczerniony i zmuszony do rezygnacji z pełnionej funkcji. Natomiast bliższe informacje o sobie Grzegorz zawarł w następnym liście, opisując pokrótce swoje przeżycia. Kończy je słowami: „Pomyśl o tym - i za tę potwarz dzięki wyznaj Bogu, choć nie tym, którzy to zrobili" ${ }^{16}$. Biskup zatem odwołuje się Opatrzności, zalecając godzenie się $\mathrm{z}$ wolą Boga ${ }^{17}$. Szerszą refleksję w tej kwestii przedstawił w następnym liście, którego treść stanowi głębsze przemyślenie zaistniałej sytuacji w kontekście osoby Sacerdosa. Pisze do niego:

„Wszystko inne niech się tak ma, jak Bóg zrządzi, [...]. Zna uzasadnienie tych rzeczy Zawiadowca życia naszego. Jednego się tylko bójmy: niefilozoficznego duszy nastroju"18.

Myśli zawarte w tych listach miały uspokoić duszę Sacerdosa, i skłonić go do powierzenia siebie Bogu, do czego bardzo usilnie przekonywał Nazjanzeńczyk.

W korespondencji Grzegorza znajdują się także listy słane do diakonów. Jednym z nich był Georgiusz, który został poproszony do zdania relacji z przykrego wydarzenia. Inny bowiem diakon obłożył chłostą pewnego człowieka, na co Grzegorz stanowczo zareagował. Pisze do Georgiusza: „Niech się stawi i diakon, by odpowiadać na skargę i spotkać się z napiętnowaniem za zdrowie skatowanego"19. Biskup nie mógł pozostawić tej sprawy bez wydania osądu nad winowajca. W tym wydarzeniu ujawnia się jego postawa wychowawcza względem diakona oraz uszanowanie godności ludzkiej.

Natomiast wśród mnichów jednym z odbiorców listów Grzegorza był Homofroniusz, początkujący mnich, który z tego powodu otrzymał słowa pochwały: „Dowiaduję się, że wiedziesz żywot pustelniczy: obyś nam się stał Janem Chrzcicielem lub Eliaszem z Karmelu!"20. Tak sformułowane gratulacje zawierają zachętę do osiagnięcia wyżyn duchowych na miarę osób biblijnych. Autor listu wybrał Jana Chrzciciela i Eliasza jako wzorcowych i dobrze znanych powszechnie przedstawicieli pustyni.

Tenże Homofroniusz kilka lat później został wtajemniczony w sprawę Sacerdosa, zwłaszcza że był z nim zaprzyjaźniony. Grzegorz pokrótce przedstawił mu przyczyny konfliktu i prosił o pomoc. Swoją relację kończy słowami:

${ }^{16}$ Tenże, Epistula 214 [Sacerdoti], PG 37, 349C, POK 15, 261.

${ }^{17}$ Szerzej przesłanie tego listu przedstawia A. Cataldo, Come l'oro nel crogiuolo (Greg. Naz. Ep. 214 e Sap. 3,5,6), „Quaderni dell'Istituto di Lingue e letterature Classiche” 2 (1983) 17-27.

${ }^{18}$ Gregorius Nazianzenus, Epistula 215 [Sacerdoti], PG 37, 353A, POK 15, 261-262.

${ }^{19}$ Tenże, Epistula 149 [Georgio], PG 37, 256A, POK 15, 193.

${ }^{20}$ Tenże, Epistula 99 [Homophronio], PG 37, 172C, POK 15, 128. 
„Okażemy przynajmniej łagodność i zwyciężymy zawiść, nie dając żadnej podchwytki ludziom, którzy nas daremnie nienawidzą"21.

Biskup kieruje się łagodnością jako jedyną drogą do opanowania zawiści. Szlachetne postępowanie w sporze gwarantuje bowiem pozytywne rozwiązanie, czego wymaga Grzegorz od siebie i adresata.

Inny mnich, Eudocjusz, był zamieszany w wyżej opisywaną sprawę oczernienia Sacerdosa. Grzegorz zachęca mnicha do rozpatrzenia zaistniałego wydarzenia, proponując siebie na rozjemcę. Poszukuje mimo wszystko dobra i tak nawołuje:

„Chciałbym, byście ułożywszy dobrze wzajemne sprawy, biskupowi usłużność okazali, zgorszenie wielu usunęli, co zaś z wszystkiego najważniejsze, Boga przebłagali i rzeczy tak wielkiej, tak chwalebnej - mam na myśli zgodę waszą i postanowienie życia Bożego - w tak krótkim czasie nie burzyli’’22.

Grzegorz dosyć stanowczo zwraca się do mnicha, wymieniając różne aspekty pojednawczych gestów. Przede wszystkim ma na uwadze doprowadzenie do zgody zwaśnionych stron. Owocami osiągniętej zgody są: okazanie usłużności biskupowi, usunięcie zgorszenia wielu i przebłaganie Boga. Ten list pokazuje, jak bardzo Grzegorz pragnął pokoju, zgody, a przede wszystkim duchowej doskonałości, która okazuje się być najlepszym rozwiązaniem w sytuacjach kryzysowych, także w tej obecnej.

W tym samym duchu został napisany kolejny list do Eudocjusza, w którym Grzegorz ponawia prośbę kierowaną do adresata: „Jeślibyś więc przynajmniej teraz się zmienił i uleczył swą przewinę, to przyszłoby może jakieś zabliźnienie, acz z trudem" ${ }^{23}$. W tych słowach zawiera się oskarżenie mnicha o spowodowanie zaistniałej sytuacji i jednocześnie usilna prośba Grzegorza, by adresat przyznał się do winy i odciążył Sacerdosa. Biskup w tym liście nie kieruje się cichą zachętą do zmiany duchowego oblicza adresata, jak to ma często miejsce $w$ jego listach, ale tym razem wręcz nawołuje go do wewnętrznej przemiany i wyjawienia swojej winy. Następny list do Eudocjusza zawiera kilka dalszych wyjaśnień Grzegorza tej skomplikowanej sytuacji wraz z docenieniem adresata, co do jego mądrości życiowej (filozofii) i dołączeniem przestrogi dotyczącej relacji międzyludzkich ${ }^{24}$.

Śmierć opata była okazją do napisania listu do mnichów i mniszek. Pośród wielu wzniosłych myśli godne uwagi są następujące słowa:

„Tego wam bowiem życzę, by każdy i każda z was urabiał się na wzór życia owego błogosławionego, byście patrząc na siebie wzajem, przeświadczeni byli, że wpatrujecie się w jego odbicie. Niech urabia wasze życie jego czy-

\footnotetext{
${ }^{21}$ Tenże, Epistula 221 [Homophronio], PG 37, 361B, POK 15, 268.

${ }^{22}$ Tenże, Epistula 216 [Eudocio], PG 37, 353A-B, POK 15, 263.

${ }^{23}$ Tenże, Epistula 217 [Eudocio], PG 37, 353C, POK 15, 264.

${ }^{24}$ Por. tenże, Epistula 218 [Eudocio], POK 15, PG 37, 356B-C, 264-265.
} 
stość, łagodność, pokora, jego dzielna filozofia, ciąłe zwrócenie duszy ku Bogu, niechwiejność wobec złud tego życia - byście widząc te zalety w sobie pomnik jego we własnych sercach wystawili" ${ }^{25}$.

Przytoczony fragment listu mieści w sobie kilka elementów przekazu korespondencyjnego: pocieszenie po odejściu bliskiej osoby, wskazanie na wzór doskonałego życia oraz zachętę do czerpania przykładu dla własnej doskonałości. Ponadto biskup wymienił te cnoty życia opata, które składają się na istotę duchowości chrześcijańskiej.

2. Wobec świeckich. Grzegorz cieszył się dużym autorytetem zarówno w stolicy w czasie pełnienia swoich obowiązków pasterskich, jak w rodzinnych stronach, w których ciagle żywe pozostawały przyjacielskie relacje. Jego korespondencja kierowana jest bowiem niezwykle często do osób spoza kręgu ściśle kościelnego. W zdecydowanej większości adresaci są zidentyfikowani, gdyż z treści listów wynika kim byli, zwłaszcza gdy Grzegorz wysłał ich więcej do danej osoby. Rzadko się zdarza, że odbiorcy jego listów pozostają w sferze anonimowości. Filagriusz, który jest odbiorcą listu po powrocie Grzegorza w rodzinne strony, był jego bliskim przyjacielem z okresu studiów w Atenach ${ }^{26}$. Po prawie trzydziestu latach Grzegorz pociesza go w chorobie poprzez kontakt listowny. Dopytuje się o kondycję cielesną, a także nawiązuje do stanu duchowego:

„O duszę nie pytam, jak się ma. Wiem ci, że wprost świetnie, bo dzielnie filozofią uśmierzasz cierpienia ciała, biorąc ten stan jakby za próbę cnoty. [...] Dajesz i tym dostateczny dowód ducha filozoficznego, że zalecasz mi podobny nastrój w podobnych chwilach"27.

Nazjanzeńczyk, pocieszając bliskiego mu Filagriusza, czerpie również dla siebie siły w ,podobnych chwilach” - jak się wyraził. Adresat jest dobrze znany Grzegorzowi, także jego duchowe zalety, więc docenia je, gdyż w chorobie okazują się doskonałą pomoca. Wspomina jego filozofię i ducha filozoficznego, czyli kierowanie się mądrością życiową, a cierpienia stają się dla niego próbą cnoty. Te myśli, które skierował Grzegorz do Filagriusza, nie są nawoływaniem do doskonałości, bo nie muszą nimi być, ale stanowią zachętę do podtrzymywania tego stanu ducha u adresata.

Leoncjusz to kolejny odbiorca listu Kapadocczyka. Nie wiadomo, czy należy go utożsamiać z prezbiterem o tym samym imieniu ${ }^{28}$, którego Grzegorz polecał namiestnikowi Olimpiuszowi, aby go ułaskawił z powodu popełnionego występku. Obok wspomnienia o własnej chorobie Nazjanzeńczyk dodał:

\footnotetext{
25 Tenże, Epistula 238 [Ad monachos et monachas], PG 37, 381B, POK 15, 283.

${ }^{26}$ Por. tenże, Epistula 30 [Philagrio], PG 37, 65C - 67A, POK 15, 123.

27 Tenże, Epistula 92 [Philagrio], PG 37, 165C, POK 15, 44-45.

${ }^{28}$ Por. tenże, Epistula 143 [Olympio], PG 37, 215A, POK 15, 187.
} 
„U was zaś jak stoją sprawy Boże? Niechby te były w porządku; na wszystko inne, jakkolwiek będzie, machniemy ręką"29.

Uwaga autora listu przenosi się w tej wypowiedzi na sferę życia chrześcijańskiego, a konkretnie - na sprawy Boże. Prawdopodobnie te słowa odnosiły się do regularnego wypełniania zobowiązań wynikających z przyjęcia chrztu, jak m.in. uczestniczenie w Eucharystii, praktykowanie modlitwy, niesienie pomocy biednym. Biskup zaleca, by te kwestie były ciagle obecne, inne natomiast można potraktować z mniejszą powagą. Pytanie postawione na początku świadczy o głębokim zainteresowaniu, a może zaniepokojeniu Grzegorza poziomem życia chrześcijańskiego adresata.

Znaczącą postacią z kręgu osób bliskich Grzegorzowi był Olimpiusz, prefekt Kapadocji Drugiej. Nie wypadało biskupowi kierować do niego zachęt w postaci napomnień, ale raczej słowa życzeń do zdobywania dalszych sukcesów. Dlatego list Grzegorz rozpoczyna w ten sposób:

„Wszystkie inne łaski, jakich dostapiłem, wiem, że twojej zawdzięczam uprzejmości - niech ci je Bóg swoimi wynagrodzi dobrami, a wśród nich tym, byś urząd swój chwalebnie i świetnie wykonał”30.

Przytoczone słowa ukazują zaufanie, jakim Grzegorz i Olimpiusz darzyli się nawzajem, a nawet zawierają podziękowanie kierowane do adresata za otrzymaną od niego pomoc. W zamian biskup błogosławi pracę Olimpiusza słowami, których treść dotyczy urzędu przez niego sprawowanego. Grzegorz pragnie bowiem, by był wykonywany chwalebnie i świetnie, a więc w sposób doskonały. W tym przypadku swe zatroskanie Grzegorz przenosi z osoby na rzeczywistość, która także powinna posiadać znamiona doskonałości.

Olimpiusz, jako namiestnik Kapadocji, był zatem odpowiedzialny za rządy w lokalnej społeczności wedle ówczesnego prawa. Jak się okazuje, mógł on także wpłynąć na decyzje odnoszące się do obsadzania biskupów. Grzegorz prosi go, aby nie zatwierdzano biskupa wybranego przez apolinarystów. Apeluje do niego:

„Jeżeli to rzecz znośna, to niech to ścierpi twoja nieugiętość, zniosę to i ja, jakem to już nieraz zniósł. Jeśli zaś to sprawa poważna i nawet najostrożniejsi cesarze podobnych nie cierpieli - racz przeciw temu, co się stało, wystapić, choć łagodniej, niż to zuchwalstwo zasługuje"'31.

Obok widocznej u Grzegorza postawy odpowiedzialności za Kościół lokalny da się także u niego zauważyć umiejętność wykorzystania pozytywnych cech, jakimi wyróżniał się Olimpiusz. Odwołując się do jego nieugiętości i ostrożności, a nawet dyplomacji, podkreśla tym samym te zalety, które są potrzebne do zarządzania i wydawania trafnych rozporządzeń.

\footnotetext{
${ }^{29}$ Tenże, Epistula 95 [Leontio], PG 37, 169A, POK 15, 125.

${ }^{30}$ Tenże, Epistula 104 [Olympio], PG 37, 204C, POK 15, 154.

${ }^{31}$ Tenże, Epistula 125 [Olympio], PG 37, 220B, POK 15, 167.
} 
Natomiast inne zalety Olimpiusza Grzegorz wymienia w liście, w którym poleca mu żołnierza, będącego dezerterem. Początek listu zawiera laudację osoby Olimpiusza ze szczególnym zwróceniem uwagi na cechy jego charakteru, którymi są: śmiałość, rozsądek, męstwo, czystość rąk, a nadto nazwany został znawcą spraw duchowych i uzdrawiaczem stosunków społecznych ${ }^{32}$. Należy przyznać, że są to cechy, które ukazują namiestnika jako wytrawnego zarządcę Kapadocji. Wyliczenie tych zalet miało bez wątpienia mobilizować adresata do rozwijania ich aniżeli do pomniejszania. Był to także swoisty sposób przynaglania Olimpiusza do dbałości o doskonałość sfery duchowej.

W kolejnym liście posłanym do Olimpiusza, kapadocki biskup ośmielił się w nieco surowszych słowach zwrócić się do niego, apelując przy tym do jego duchowej wrażliwości. Sytuacja była poważna, ponieważ w Nazjanzie wywołano zamieszki, w następstwie czego Olimpiusz zagroził zburzeniem miasta. Wówczas zareagował na to wydarzenie Grzegorz, który w nieco dłuższym liście wykłada swój punkt widzenia, prosząc adresata o wyrozumiałość:

„Przyjmij moje upomnienie jak od przyjaciela. Zechciej nauczyć rozumu tylko tych, którzy zgrzeszyli przeciw zarządzeniu twej władzy. [...] Ale nadmiernego gniewu zaniechaj i użyj większego zastanowienia!"’33

Ten fragment listu zawiera zdecydowanie nieco większe zaangażowanie emocjonalne Grzegorza, który w tonie rozkazującym proponuje Olimpiuszowi dalsze postępowanie w celu rozwiązania lokalnego konfliktu. Używa takich sformułowań, jak: ,przyjmij moje upomnienie”, ,zechciej nauczyć rozumu”, „gniewu zaniechaj”, „użyj większego zastanowienia”. U podłoża takiego zachowania Grzegorza leży bez wątpienia znajomość adresata i jego zalet, dlatego Nazjanzeńczyk mógł pozwolić sobie na tak śmiały słowny gest. Ponadto sprawa dotyczyła Nazjanzu, a więc miejsca urodzenia Grzegorza. Lokalny patriotyzm był więc nośnikiem dosyć kategorycznych zwrotów kierowanych do namiestnika Kapadocji. Zakładana przez Grzegorza ostatecznie pozytywna decyzja Olimpiusza tkwi zatem w walorach charakteru adresata. Niebawem potwierdziła się ona, o czym świadczy treść kolejnego listu, w którym Grzegorz złożył podziękowanie za wysłuchanie jego prośby. Dodał w nim słowa o charakterze sekwencji adresowanej do Olimpiusza: „Żadna przecież szkoda nie wyniknie dla spraw z twego miłosierdzia" ${ }^{34}$. Grzegorz bowiem zakłada, że jego miłosierdzie nie dopuści do powstania jakiejkolwiek szkody w społeczności, dla której jest namiestnikiem.

Grzegorz nie poprzestał na dotychczasowych prośbach odwołujących się do zalet Olimpiusza. Wstawiając się za pewnym prezbiterem, podkreśla jego dobroć:

\footnotetext{
${ }^{32}$ Por. tenże, Epistula 140 [Olympio], PG 37, 237BC - 240A, POK 15, 181-182.

${ }^{33}$ Tenże, Epistula 141 [Olympio], PG 37, 241A, POK 15, 184.

${ }^{34}$ Tenże, Epistula 142 [Olympio], PG 37, 244B, POK 15, 186.
} 
„Sam potrzebuję twojej uprzejmości we własnych sprawach, a oręduję za innymi i nie boję się wyczerpać twojej dobroci cudzymi sprawami" "35.

Grzegorz, prosząc o rekomendację w czyjejś sprawie, mógł w celu jej uzyskania na wyrost podkreślić zaletę dobroci Olimpiusza po to, aby prośba przyniosła oczekiwany skutek. Jednak z poprzednich listów wynika, że namiestnik Kapadocji odznaczał się wyrozumiałością wobec swoich poddanych.

Pomiędzy Grzegorzem a Olimpiuszem istniała relacja wzajemnego zaufania i otwartości na obopólną pomoc. Następny bowiem list biskupa adresowany do namiestnika jest odpowiedzią na wcześniej otrzymane od niego pismo w kwestii pozwolenia na rozwód pewnego małżeństwa, o czym musiał zadecydować. Obok ustaleń w tej sprawie i pochwał pod adresem Olimpiusza odnośnie jego zarządzania Nazjanzeńczyk dołączył słowa, będące życzeniami skierowanymi do niego. Zwraca się do niego w ten sposób:

„Uczynisz więc - rzecz jasna - to, co spodoba się twojej sprawiedliwości i wiodącemu cię we wszystkim Bogu. [...] A przestrzegać trzeba koniecznie sprawiedliwości - czego życzę tobie, byś zawsze głosił i czynił"36.

W tych słowach przewija się kolejna zaleta, która należy do istotnych cech dobrego zarządcy, a jest nią sprawiedliwość. Biskup wprawdzie dostrzega ją u Olimpiusza, ale dodaje, że należy jej koniecznie przestrzegać - jakby dawał do zrozumienia adresatowi, aby w sposób pełny kierował się nią w podejmowaniu decyzji. Dla uzupełnienia tej myśli Grzegorz dodaje jako życzenie, aby Olimpiusz ją stosował w swym życiu i głosił ją innym. W takim podejściu Nazjanzeńczyka wobec Olimpiusza widoczna jest jego pedagogia polegająca na tym, by przy różnych sytuacjach dnia codziennego proponować adresatowi odpowiednie zalety ducha, odpowiadające charakterowi tych zdarzeń.

Kolejny list adresowany do Olimpiusza zawiera prośbę Grzegorza o wyrozumiałość dla występku Nikobula, krewnego biskupa. List jest przesycony pokornymi sformułowaniami, a także słowami uznania dla zalet adresata. Grzegorz podkreśla bowiem jego życzliwość, miłosierdzie, dobroczynną wielkoduszność, nieskazitelność, lotność ducha i cnotę ${ }^{37}$. Bez watpienia wskazanie tylu zalet Olimpiusza w jednym liście miało na celu pozyskanie go dla rekomendowanej sprawy. Należy ponadto dodać, że namiestnik należał do osób wysoce urobionych duchowo, zatem przypomnienie mu przez Grzegorza tych cech oznaczało dalsze zabieganie o ich rozwój. Natomiast inny charakter ma list do Olimpiusza po jego odejściu z urzędu. Jego treść jest refleksją Grzegorza nad rządami namiestnika i złożeniem hołdu dla jego wielkości. Nazjanzeńczyk podkreśla jego zdolności władcze, wielkość autorytetu i miłosierdzie ${ }^{38}$.

\footnotetext{
35 Tenże, Epistula 143 [Olympio], PG 37, 245A, POK 15, 187.

36 Tenże, Epistula 144 [Olympio], PG 37, 248A, POK 15, 188.

${ }^{37}$ Por. tenże, Epistula 146 [Olympio], PG 37, 249A-C, POK 15, 190-191.

${ }^{38}$ Por. tenże, Epistula 154 [Olympio], PG 37, 260C - 261A, POK 15, 198-199.
} 
Podobnym duchem wyróżnia się list do Modariusza, który był dowódcą wojskowym. Grzegorz zabiega u niego o dołożenie starań, by synod biskupów zakończył się pokojowym porozumieniem. Przy tej okazji autor listu pochwala jego zalety, a wśród nich pobożność i dzielność, i dodaje: „Oby wielu z moich pobratymców naśladowało twoją szlachetność!" 39 Grzegorz, widząc w wojskowym przykład człowieka pełnego zacności, wyraża więc pragnienie, aby stał się godnym naśladowania przez jego pobratymców. W tak ujętej uwadze można dostrzec zatroskanie o wzrost duchowych wartości także u prostych mieszkańców rodzinnych stron, a nie jedynie u osób piastujących jakieś stanowiska.

Keleuzjusz był natomiast urzędnikiem miejskim w Nazjanzie. Był więc dobrze znany Grzegorzowi co do jego zachowań. List, który biskup do niego skierował, uchodzi za bardzo surowy w całej jego treści. Pisze doń m.in.:

„Źle czynisz sędzio, że nie pościsz. Lecz jak masz przestrzegać praw ludzkich, skoro boskie za nic masz? Oczyść swą sędziowską stolicę, by jedno z dwojga nie nastąiło: byś albo stał się złym albo za takiego uchodził. Urządzać szpetne widowiska to z siebie samego widowisko robić!"40

Zdecydowanie większa część tego listu stanowi treść napominającą. Grzegorz bowiem bardzo negatywnie odbierał działalność sędziego, który postawami swej osobowości i formami aktywności zawodowej prezentował siebie w rodzinnej miejscowości biskupa - Nazjanzie. Poznał go bliżej podczas odwiedzin w domu Grzegorza. Dlatego list mógł być kontynuacją wcześniej zapoczątkowanych wątków w czasie rozmowy. Przede wszystkim Nazjanzeńczyk wyrzuca Keleuzjuszowi brak postu, czyli lekceważenie podstawowej zasady obowiązującej chrześcijan w okresie Wielkiego Postu ${ }^{41}$, jak wynika z wcześniejszego zdania listu. Zachowanie bowiem postu może spowodować oczyszczenie „sędziowskiej stolicy”, jak się wyraził autor listu, a to z kolei powinno doprowadzić do zaniechania urządzania dla mieszkańców niestosownych widowisk. Ta informacja koresponduje z często spotykaną jeszcze w IV w. modą na wystawianie w miastach Imperium widowisk różnego typu ${ }^{42}$. Grzegorz ma nadzieję, że słowa słane do sędziego przyniosą oczekiwany skutek.

Pochlebnie wyraził się Grzegorz o Asteriuszu, który był urzędnikiem współpracującym z Olimpiuszem. Polecając mu w pewnej sprawie diakona

\footnotetext{
${ }^{39}$ Tenże, Epistula 136 [Modari exercitus duci], PG 37, 232C, POK 15, 178.

${ }^{40}$ Tenże, Epistula 112 [Celeusio], PG 37, 209A, POK 15, 157.

${ }^{41}$ Sposoby praktykowania postu w codzienności chrześcijańskiej ukazuje antologia wypowiedzi Ojców Kościoła, którą opracował M. Pappalardo, Wielki Post i Wielkanoc z Ojcami Kościoła, thum. M. Dobosz, Warszawa 2010.

${ }^{42}$ Złożona problematyka widowisk w starożytności chrześcijańskiej stała się przedmiotem badawczym licznych studiów. Zob. przykładowo niektóre z nich: J. Śrutwa, Widowiska epoki klasycznej w ocenie Kościoła afrykańskiego II-V w., RTK 27 (1980) z. 4, 43-56; S. Longosz, Widowiska teatralne zagrożeniem dla życia rodzinnego według św. Jana Chryzostoma, w: Chrześcijanie a życie publiczne w Cesarstwie Rzymskim III-IV w., red. J. Śrutwa, Lublin 1988, 135-198.
} 
Georgiusza, nawiązuje do duchowej sfery adresata i dodaje: „Dzierżno dalej pierwszeństwo $\mathrm{w}$ cnocie, a mnie wybacz unikanie natręctwa" ${ }^{43}$. Biskup już wcześniej zauważył pozytywne cechy osobowości Asteriusza, dlatego przy obecnej okazji pisania listu zachęca go, aby „dalej” prowadził dobre życie. Grzegorz tymi słowami dowartościował zalety urzędnika i jednocześnie delikatnie poprosił o dalsze utrzymanie tej duchowej kondycji. Na kanwie tego dołączył osobistą prośbę o umiejętność wybaczenia, co odniósł do własnego natręctwa. W kolejnym liście wysłanym do niego, biskup kontynuuje narracje na temat zalet adresata, pisząc:

„Chwalę go z wielu względów, a najwięcej podziwiam to, że zachowując tyle zapału dla spraw państwowych, znajdujecie miejsce i na obowiązki przyjaźni: szorstkością postępowania nie podkreślacie ścisłości prawa na wzór wielu nieumiarkowanych, lecz raczej łagodzicie uprzejmością - surowość władzy" ${ }^{44}$.

Powyższe słowa stanowią ostatni fragment listu, w którym ich autor zamieścił pochwałę adresata, wymieniając kilka jego zalet. Podkreśla bowiem jego zapał społeczny, podtrzymywanie przyjaźni oraz uprzejmość w sprawowaniu władzy, przeciwstawiając go negatywnemu wizerunkowi władcy, którego cechuje szorstkość postępowania, nieumiarkowanie i surowość władzy. Tego typu opinia o lokalnym urzędniku świadczy o wrażliwości Grzegorza na jakość postaw duchowych poszczególnych osób. Jedne pochwala, drugie gani, co w odbiorze ich przez Asteriusza miało oznaczać, by nadal trwał przy dotychczasowym sposobie sprawowania piastowanego urzędu.

Bardzo cennym dla niniejszych rozważań jest list do Tymoteusza, jako jedyny adresowany do niego w całej korespondencji Grzegorza. Jego treść prawie w całości stanowi studium duchowości reprezentowanej przez adresata, jak i przez samego Grzegorza. Najpierw biskup skupia się na Tymoteuszu, wymieniając jego zalety, którymi są: „wykształcenie, pobożność, łagodność i skromność, których zogniskowanie w jednej duszy jest nad wyraz trudne"45. Z listu wynika, że Tymoteusz to bliżej nieznany chrześcijanin, który zaangażował się w szerzeniu właściwej nauki o Trójcy Świętej, pozostający w stałej łączności listowej z Grzegorzem. Bez wattpienia uznał go za autorytet w tym względzie, gdyż wygłoszone mowy o Trójcy Świętej w Konstantynopolu były już znane $w$ innych rejonach wschodniej części Imperium ${ }^{46}$. Biskup zatem zdołał go na tyle poznać, by w tym jedynym zachowanym liście opisać jego osobowość. W dalszej jego części zachęca go do pogłębiania swej duchowości, dodając: „Ale ty bądź mężny, krzep się i walcz o Trójcę co sił!”47 Psychologię

\footnotetext{
${ }^{43}$ Gregorius Nazianzenus, Epistula 150 [Asterio], PG 37, 256B, POK 15, 194.

${ }^{44}$ Tenże, Epistula 156 [Asterio], PG 37, 264B, POK 15, 200.

${ }^{45}$ Tenże, Epistula 164 [Timotheo], PG 37, 272C, POK 15, 205.

${ }^{46}$ Wspomina o tym M. Simonetti, La crisi ariana nel IV secolo, Roma 1975, 498-499.

${ }^{47}$ Gregorius Nazianzenus, Epistula 164 [Timotheo], PG 37, 273A, POK 15, 206.
} 
takiej taktyki wobec Tymoteusza, a także innych adresatów, Grzegorz odkrywa w innych słowach tego listu:

„I pamiętasz o mnie i listami mnie witasz i dodajesz pochwały, nie żeby mnie chwalić - rozumiem się na twojej filozofii - lecz żeby mnie lepszym uczynić i popchnąc naprzód przez wstyd, że nie okazuję się takim, za jakiego mnie masz"48.

Przytoczone słowa ukazują sposób zwracania się do adresatów: obok wyraźnej pochwały odnoszącej się do dokonań odbiorcy listu, często z wyliczeniem jego zalet, Grzegorz zachęca go następnie do wytrwania na obranej drodze duchowej lub też do zdobycia innych wartości. Pochwała, jak sam to przyznaje biskup, powinna „uczynić lepszym i popchnąć naprzód”. Ponadto powinna ona zmobilizować adresata do ukazania prawdziwego oblicza, a nie jego zafałszowania. Jak można zauważyć, Nazjanzeńczyk tego typu metodę zwracania się do swoich korespondentów stosuje prawie powszechnie.

Inny natomiast ton jest obecny w liście do sofisty Stagiriusza. Z treści wynika, że nieco szorstko odniósł się Grzegorz do niego, mimo że wcześniej spotkała adresata bliżej nieokreślona przykrość. Biskup swój list rozpoczął dosyć zdecydowanie:

„Dowiaduję się, że twą przykrość niefilozoficznie znosisz - nie chwalę tego.

[...] Nie chwalę ani zbytniej niewrażliwości ani przesadnej nadwrażliwości.

[...], zatop się w sobie i w książkach, z którymiś w dobrej przyjaźni: w nich wiele żywotów, wiele charakterów, wiele rozkoszy i powodzeń, wiele też, jak oczywista, nieszczęść i potykań"49.

Niezależnie od ciężkiego położenia Stagiriusza, Grzegorz go nie oszczędza, ale podnosi na duchu poprzez wyrzucanie mu braku umiejętności radzenia sobie w życiu. Adresat bowiem nie potrafi wykorzystać sofistycznej mądrości, jest zbytnio wrażliwy, co oznacza, że za bardzo skupiony jest na sobie. Dlatego biskup odsyła go do książek, które zawierają wiele pouczeń i gotowych rozwiązań na życiowe tragedie. Czyni tak, ponieważ adresat jest człowiekiem wykształconym i powinien umieć poprzez lekturę książek pomóc sobie. Pedagogia i pomoc kierowana do sofisty przybiera następnie postać na wskroś chrześcijańską, gdyż Grzegorz postrzega zachowanie Stagiriusza w Bożej perspektywie i dodaje:

„Splata to wzajem Bóg: jak mi się zdaje, żeby ani smutek nie był nieuleczalny ani radość niekarna, ażebyśmy bacząc na niestałość i nierówność w tych rzeczach, na Niego jedynie oczy obrócili. Wręczam ci to jako prawidło i miernik dla twego cierpienia" ${ }^{50}$.

\footnotetext{
${ }^{48}$ Tamże, PG 37, 272C - 273A, POK 15, 206.

${ }^{49}$ Tenże, Epistula 165 [Stagirio], PG 37, 273B, POK 15, 206-207.

${ }^{50}$ Tamże, PG 37, 273C, POK 15, 207.
} 
Biskup wymienia dwa przeciwległe stany ducha, którymi są smutek i radość, a przeżywane przez człowieka rozterki i przykrości przesuwają ów duchowy stan albo w kierunku smutku, albo w stronę radości. Dostrzega bowiem niestałość i nierówność doznawanych każdego dnia przeżyć. Dlatego Grzegorz, chcąc okazać duchowe wsparcie Stagiriuszowi, częściowo identyfikuje się $\mathrm{z}$ adresatem i podaje, także we własnym imieniu, dalsze kroki postrzegania swego życia w kontekście Bożej Opatrzności, co wyznaje następująco:

„bo przecież słowo Boże wynosi nas ponad obecność i zaleca nam pomijać te niby cienie i zagadki i ani tego, co boli, ani tego, co cieszy, za prawdę nie brać, lecz żyć gdzie indziej - tam patrzeć - jedyny znać smutek: grzech; jedyną radość: cnotę i zażyłość z Bogiem. Takimi myślami urzeknij siebie, a lżej ci będzie" 51 .

Te słowa, stanowiąc ostatni fragment listu, zawierają przyjacielskie pocieszenie, będące jednocześnie wskazaniem drogi wyjścia z duchowej zapaści, gdzie jedynym sposobem jest refleksja nad słowem Bożym, które wprowadza dystans i beznamiętność w ,te niby cienie i zagadki”. Grzegorz powraca do poprzednio reflektowanej myśli dotyczącej dwóch przeciwstawnych uczuć, zalecając, by smutek wiązać z grzechem, a radość z cnotą i zażyłością z Bogiem. W tych spostrzeżeniach kryje się bogate doświadczenie Grzegorza, zwłaszcza z czasów jego posługiwania na stolicy biskupiej, gdy sam osobiście doznawał wielu różnych przykrości. Patrząc na nie z czasowego dystansu, mógł do Stagiriusza napisać, aby „ani tego, co boli, ani tego, co cieszy, za prawdę nie brać”.

Stagiriusz poczuł się nieco urażony dość stanowczymi stwierdzeniami Grzegorza, co wynika z kolejnego listu posłanego do niego. Biskup odsłonił ponadto taktykę swego działania, na co uwagę zwracają początkowe słowa listu:

„Była - mój kochany - jakaś korzyść z mego listu, może nie najmniejsza: tęgim jestem lekarzem takich chorób! Wytrąciła z ciebie smutek ma przygana, rumieniec zastąpił ból" ${ }^{\prime 52}$.

Grzegorz wyraźnie nawiązuje do treści poprzedniego listu, a zwłaszcza sytuacji duchowej, w której znalazł się Stagiriusz. Wyraża swą radość, że był w stanie pomóc adresatowi, ponieważ smutek minął, a zamiast bólu na twarzy pojawił się rumieniec. Obok wyżej wspomnianej taktyki pomocy, zarysowującej się w strukturze treści poprzedniego listu, biskup w niniejszym liście wprost pisze o swoich możliwościach i chwali siebie, dodając: „tęgim jestem lekarzem takich chorób". Tego typu oświadczenie oznacza, że biskup był skuteczny w niesieniu duchowego wsparcia potrzebującym. W innym liście do Stagiriusza wprost przyznaje się do tego posłannictwa w refleksji

\footnotetext{
${ }^{51}$ Tamże, PG 37, 276A, POK 15, 207.

${ }^{52}$ Tenże, Epistula 166 [Stagirio], PG 37, 276B, POK 15, 208.
} 
o dialogowym charakterze: „Zaprawiasz do myśli i słów? Ja do życia duchowego"s3. Jak wiadomo, Stagiriusz był sofistą, a więc zawodowym nauczycielem w zakresie przemawiania. Wprawdzie Grzegorz także ukończył studia z retoryki, to jednak bardziej podkreślał u siebie działalność w zakresie życia duchowego, co wypływało z misji kapłańskiej.

Pewnego razu Nazjanzeńczyk musiał zaingerować w kłótnię pomiędzy Stagiriuszem a Eustachiuszem, który też był sofistą:

„Złóżcie raz przecież oręż i te proce i te straszniejsze dziryty - języki wasze którymi się obrzucacie i ranicie, a to wśród oklasku waszych popleczników"54.

Ta wypowiedź jest także troską Grzegorza o poziom duchowy jego znajomych sofistów. Ich kłótnie i zaczepki słowne nie należały - w ocenie biskupa - do wzniosłej kultury osobistej, dlatego ośmielił się takie ich zachowanie piętnować, a nawet nakazać zaprzestanie zaistniałego sporu.

Grzegorz dostrzegał nie tylko wady i niedomagania swoich korespondentów, ale także potrafił docenić wartości, które ich wyróżniały. Przykładem takiego zachowania są słowa listu do Strategiusza, mieszkańca Konstantynopola:

„O święte ognisko, święte małżeństwo, wspólna przystań wszystkich bojących się Pana! Inni korzystają z dóbr waszych: mnie pozostało wspomnienie tylko i zazdroszczenie uczestniczącym w nich"55.

Małżeństwo Strategiusza, a także jego rodzina, należało do kregu bliskich osób Grzegorza z czasów jego zasiadania na stolicy biskupiej. Pochwała, którą kieruje do adresata, jest zachętą do podtrzymywania świętości panującej w tej rodzinie. Blask tej świętości musiał być ogromny, że Nazjanzeńczyka ogarnia zazdrość wobec tych, którzy uczestniczą w życiu tej bogobojnej rodziny. Podkreślenie jej zalet było wypowiedziane w kontekście rekomendacji prezbitera Sacerdosa, aby został odpowiednio przyjęty i potraktowany w stolicy. W podobny sposób Grzegorz polecił go urzędnikowi Palladiuszowi, podkreślając jego dobroć i przezacnośćc 56 .

Do sławy i autorytetu odwołał się Grzegorz, gdy pisał list do Postumiana, prefekta pretorianów, w sprawie nadzoru nad synodem, mającym się odbyć w 383 r. w Konstantynopolu. Nazjanzeńczyk podkreśla wykształcenie adresata i cnotę, ,aby i sama ta władza zacniejszą się stała"57. Dla Grzegorza, jak wynika $\mathrm{z}$ tych słów, istotne jest duchowe wyposażenie, które jest ważne zwłaszcza przy sprawowaniu zaszczytnej funkcji państwowej.

Kilka listów od Grzegorza otrzymał retor Eudoksjusz, który pochodził z Kapadocji i który był wychowawcą Nikobula. Biskup chwali jego

\footnotetext{
${ }^{53}$ Tenże, Epistula 188 (Stagirio], PG 37, 308B, POK 15, 232.

${ }^{54}$ Tenże, Epistula 192 [Stagirio], PG 37, 316A, POK 15, 237.

${ }_{55}$ Tenże, Epistula 169 [Strategio], PG 37, 277D - 279A, POK 15, 210.

${ }^{56}$ Por. tenże, Epistula 170 [Palladio], PG 37, 280B, POK 15, 211.

${ }^{57}$ Tenże, Epistula 173 [Postumiano], PG 37, 284A, POK 15, 213-214.
} 
osobowość, w której dostrzega wiele pozytywnych cech: przede wszystkim ceni jego przyjaźn, dzielność w funkcji wychowawczej oraz gorliwość nauczycielską ${ }^{58}$. W kolejnym liście pobudza go do pomnożenia właśnie gorliwości, gdyż Nikobul okazuje się być leniwym chłopcem ${ }^{59}$. W innym chwali jego sztukę retoryczną i umiejętności sofistyczne ${ }^{60}$. Natomiast w następnym wprost Grzegorz pyta Eudoksjusza: „Jak z postępem w cnocie? Czyśmy się po myśli Bożej nieco naprzód posunęli? Myślę, że to bardziej, niż wszystko, tobie odpowiada" ${ }^{61}$. Te stwierdzenia dowodzą, że Eudoksjusz okazywał się dla Grzegorza ważną osobą, m.in. dlatego, że posiadał takie samo wykształcenie, tj. w sztukach retorycznych. Mógł więc przewidzieć, jakie mogą go trapić problemy duchowe, mimo że nie był biskupem. Sofista troszczył się bez wątpienia o jakość swego ducha, o czym mógł wiedzieć Grzegorz, skoro pyta go o postępy w cnocie, a nawet zakłada, że posuwanie się naprzód na drodze swej duchowości bardziej mu odpowiada.

Kolejny list wysłany do Eudoksjusza ma charakter skondensowanego traktatu na temat teologii duchowości. Jest to jeden z dłuższych listów zachowanych pośród korespondencji Nazjanzeńczyka, zawierający wiele wskazówek odnoszących się do poszukiwania dróg ku doskonałości. Treść pierwszej jego części odnosi się do osobowości adresata, dlatego Grzegorz tak mu doradza:

„I ty - twierdzę - powinieneś, ponieważ stworzony jesteś do filozofii, nie zaniedbywać jej [...], nie tylko dlatego, że jest najlepsza, lecz że tobie bardziej przyrodzona"62.

Biskup utwierdza Eudoksjusza, aby trwał przy raz obranym zajęciu, tj. sofistyce, która prowadzi do umiłowania mądrości, czyli filozofii. Wypowiedź Grzegorza zdradza ponadto u niego znawstwo ludzkiej psychiki, skoro dodał, że filozofia jest mu „bardziej przyrodzona”. Wnikanie w usposobienia ludzi należało do charakterystyki osobowości Grzegorza, co mogą ilustrować następujące jego słowa pisane do Eudoksjusza:

„Otóż, gdym ci się przypatrywał, uderzyły mnie: najpierw ten zasadniczy nastrój, to usposobienie pogodne i proste, do matactw tego życia niestworzone; następnie ten umiar i wzniosłość duszy oraz skłonność do rozmyślania. [...], a ubóstwem nie tyle zdajesz mi się gnębić, ile raczej nim szczycić. Umiesz się i wstydzić - co nie jest retorów zwyczajem" ${ }^{3}$.

Ten dłuższy fragment listu pokazuje umiejętności Grzegorza do rozpoznawania charakteru dusz ludzkich, określania ich jakości, a przede wszystkim

\footnotetext{
${ }^{58}$ Tenże, Epistula 174 [Eudoxio], PG 37, 285A-B, POK 15, 215-216.

${ }^{59}$ Tenże, Epistula 175 [Eudoxio], PG 37, 285C, POK 15, 216.

${ }^{60}$ Tenże, Epistula 176 [Eudoxio], PG 37, 288B-C, POK 15, 218.

${ }^{61}$ Tenże, Epistula 177 [Eudoxio], PG 37, 288C - 289A, POK 15, 218.

${ }^{62}$ Tenże, Epistula 178 [Eudoxio], PG 37, 289B, POK 15, 219.

${ }^{63}$ Tamże, PG 37, 292A, POK 15, 219-220.
} 
wskazywania dróg poprawy lub też rozwijania posiadanych zalet. W przypadku Eudoksjusza należy stwierdzić, że biskup jest zachwycony jego osobowością, pochwala ją i zachęca do trwania w posiadanych sprawnościach duszy, co wyraźnie podpowiedział adresatowi: „Nie chciej przeto wyzbywać się tego, czegoś już z filozofii nabrał" ${ }^{64}$.

Druga część listu do Eudoksjusza jest natomiast refleksją wynikającą z rozmyślań nad moralnością chrześcijańską, a więc konkretnymi zasadami postępowania w życiu. Grzegorz m.in. w ten sposób rozmyśla:

„Innym zostawmy powaby życia, w których przeważa ból. Innymi niech jak kamyczkami ciska, rzuca, igra zawiść, czas, szczęście [...]. Niech precz pójdą trony, władze, bogactwa, przepych, wyniesienie, poniżenie, ten tani, splunięcia godny rozgłosik, którym się więcej zniesławia ten, co się nim nadyma, niż ten, z kogo się śmieją - słowem igraszki i błazeństwa tej wielkiej widowni ziemskiej”"65.

Tenor tych słów zawiera doświadczenie życiowe Grzegorza: w młodości podziwiał blask wielkich miast, jak Aleksandria i Ateny, potem poddał się samotności na pustelni w Poncie, służył ludowi kazaniami u boku swego ojca, a przede wszystkim przeżył swego rodzaju „karierę” w Konstantynopolu na stolicy biskupiej. U schyłku swego życia mógł pozwolić sobie na zapisanie powyższej refleksji w liście skierowanym do człowieka mającego pokrewną duszę. Skoro dla biskupa mijają wszelkie zajęcia na „tej wielkiej widowni ziemskiej”, jak się wyraził, jego myśli w następnym passusie listu przybierają postać bardziej wzniosłą, bo dodaje:

„My obejmijmy sercem Słowo, chciejmy przede wszystkim Boga posiąść, to jedyne wystarczające dobro [...], wszak nagrodą cnoty jest stać się Bogiem i opromienić się najczystszym światłem, którego teraz skappe odblaski posiadamy" ${ }^{\text {"66 }}$.

Niewątpliwie, te słowa mają charakter swego rodzaju mistyki - zjednoczenia się z Bogiem, do czego należy dążyć, by ostatecznie dać „opromienić się najczystszym świattem". Ten stan jest nagrodą za posiadaną cnotę, a więc żywot prowadzony w duchu prawdziwej filozofii, umiłowania mądrości, szukania dobra i sprawiedliwości. Grzegorz zatem w sposób bardzo ścisły wiąże życie teraźniejsze z życiem wiecznym. Dlatego w końcowej części listu biskup, pełniąc misję odpowiedzialnego pasterza dusz, ponownie zwraca się do Eudoksjusza:

„Ku temu idź, tam podążaj, myślą wzlatuj, uchwyć się żywota wiecznego, nie ustawaj nigdy w nadziejach, póki nie dojdziesz do szczytu pożądanego i błogosławionego. I będziesz mnie - wiem to dobrze - chwalił, zrazu skąpo, wkrótce potem hojnie, gdy ujrzysz się w tym, co ci obiecuję"67.

\footnotetext{
${ }^{64}$ Tamże, POK 15, 220.

${ }^{65}$ Tamże, PG 37, 292C, POK 15, 221.

${ }^{66}$ Tamże, PG 37, 293A, POK 15, 221.

${ }^{67}$ Tamże.
} 
Grzegorz tym razem nie akcentuje poszukiwania doskonałości w ziemskim okresie życia, a raczej zwraca uwagę na niebiański jego cel. Zachęca Eudoksjusza do dążenia do żywota wiecznego całym swoim jestestwem: ciałem, wolą i umysłem, co wyrażają trzy pierwsze nakazy - idź, podążaj i myślą wzlatuj. Następnie Grzegorz wskazuje własną osobę, podkreślając swoje zalecenia co do trafnego pokierowania życiem adresata. Wydźwięk jego słów prezentuje się nieco zuchwale, co może oznaczać, że biskup w swej pracy duszpasterskiej niejednokrotnie przekonał się o słuszności stawianych komuś rad duchowych, przez co rozpoznał własne umiejętności w tym względzie. Dlatego w sposób bezpośredni ocenia w tym liście siebie i położenie adresata ${ }^{68}$.

Następny list do Eudoksjusza jest kontynuacją poprzedniego co do treści. Grzegorz wprost do niego nawiązuje, pytając:

„Co ty na to? Czy przekonywam cię tymi słowy [...]? Jeżeli ci przeto moja pobudka wystarcza, to pięknie rzecz się ma, i nie trzeba niczego więcej szukać" ${ }^{69}$.

Grzegorz zdaje sobie sprawę z tego, że w poprzednim liście zarysował ideał duchowości chrześcijańskiej, do osiagnięcia którego został zaproszony adresat. W obecnym liście biskup weryfikuje postawę Eudoksjusza, dopytując się o niektóre szczegóły, jakby prowadząc kierownictwo duchowe. Eudoksjusz z całą pewnością listownie odpowiedział na duchowe propozycje Grzegorza, utrzymując prawdopodobnie całość narracji na poziomie umiarkowanym, skoro biskup w następnym liście śle do niego inne słowa zachęty: „Jeno dźwignij się, postępuj szczęśliwie, króluj! Ja ci bluźnić nie będę, choćbyś jeszcze nie przyznawał się do filozofii" "70. Zależy zatem Grzegorzowi na wysokim poziomie mądrości życiowej, bo ta - według biskupa - jest sposobem na osiagnięcie innych walorów ducha.

Całkiem inny charakter ma treść listu do sofisty Eustochiusza, współtowarzysza z czasu studiów w Atenach, który dowiedział się, że rzekomo Grzegorz polecał Nikobula (swego krewnego) innemu sofiście, Stagiriuszowi, a nie Eustochiuszowi. Nazjanzeńczyk był zmuszony w surowych tonach odpisać koledze na jego zarzuty:

„Nie pochwalam tych przezwisk [...]. Kiedyż skończymy z tą sofistyczną napastliwością? Na co czekamy? [...], ale w tym wieku, przy takim powodzeniu bóść jeden drugiego, to zupełnie nie na miejscu, to kłótliwość; nie tylko, ponieważ jest to nieprzyzwoite i zgoła niedostojne" $"$.

Ten fragment listu, a także kolejne tu pominięte, ukazuje namiętności, słabość ludzkiej natury i ambitne międzyludzkie rywalizacje. Grzegorz zareagował na

${ }^{68}$ Doskonałą analizę tego listu zostawił A. Cataldo, Virtú e ricerca di Dio nell'epistolario di S. Gregorio di Nazianzo, „Sileno” 5-6 (1979-1980) 183-207.

${ }^{69}$ Gregorius Nazianzenus, Epistula 179 [Eudoxio], PG 37, 293B, POK 15, 222.

${ }^{70}$ Tenże, Epistula 180 [Eudoxio], PG 37, 296A, POK 15, 222.

${ }^{71}$ Tenże, Epistula 190 [Eustochio sophistae], PG 37, 309B - 312A, POK 15, 234. 
tę sytuację dosyć stanowczo, gdyż po części dotknęła także jego osobę. Przede wszystkim potępia wszelakie negatywne postawy w relacjach pomiędzy sofistami. Ma na uwadze przezwiska, napastliwość, kłótliwość, a następnie wynikającą z tego nieprzyzwoitość i niedostojność. W kolejnym nieco krótszym liście, będącym odpowiedzią na poprzedni, Grzegorz podobnie się zachowuje, nieco jednak łagodząc ton swych słów: „Bądź zdrów na ciele i duszy, a język poskramiaj, jeśli możesz!"72 Teksty tych listów stanowią przykład radykalnego podejścia Grzegorza do spraw związanych z moralnościa, a w dalszej konsekwencji także z duchowością chrześcijańską, której tajniki doskonale rozumiał.

Adresatem Grzegorza był także Nemezjusz, prefekt Kapadocji, który otrzymał kilka listów wstawienniczych. W jednym z nich biskup nawiązuje do rozpoczętej rozmowy:

„Winieneś mi bowiem według obietnicy pogadankę o naszym wyznaniu, którąś zostawił niedokończoną. A jeśli nie, ja całą stratę poniosę z ciężkim sercem [...], zapiszesz się jeszcze głębiej, gdy staniesz się Bożym i wyraźnie naszym czy my twoimi"’?3.

Nemezjusz był bowiem poganinem, którego Grzegorz starał się pozyskać dla wiary chrześcijańskiej. Owa „pogadanka o naszym wyznaniu” mogła być formą przygotowania do przyjęcia chrztu. Biskup zakłada pozytywną decyzję Nemezjusza, na czym mu bardzo zależy, a ewentualną odmowę Grzegorz przeżyje ,z ciężkim sercem”. Treść tego listu jest zatem świadectwem prowadzenia przez Nazjanzeńczyka swego rodzaju ewangelizacji. W osobistej korespondencji mógł się na taki czyn zdecydować, ponieważ adresat był prefektem Kapadocji, a więc osobą powszechnie znaną, a Grzegorz, pochodzący z tej krainy, poczuwał się do spełnienia obowiązków pasterskich także względem niego.

Adelfiusz to młodzieniec pochodzący ze szlachetnego rodu. List Grzegorza adresowany do niego zawiera opis sposobu życia i manier panujących w takich rodzinach, co miało uświadomić młodemu odbiorcy czyhające na niego zagrożenia. Pośród wielu myśli zawartych w liście do Adelfiusza, niektóre ukazują także linie duchowego kierownictwa sprawowanego wobec niego przez Grzegorza:

„Dobrze! Początki przedstawiają się nawet bardzo pięknie. Chwalimy cnotę, obaj ku Bogu się skłaniamy, [...]. Przede wszystkim uprzejmość twoja, prostota i wytworność twoich obyczajów - spotykana rzadko i u nielicznych posuwa mnie do tej śmiałości. [...] Wystarczy tyle dla twej doskonałości, i to już może więcej, niż na rozmiary listu" "ᄁ4.

Na przytoczone słowa składają się trzy krótkie urywki listu. Pierwszy passus stanowi pochwałę adresata za jego duchowe osiagnięcia, będący swego

\footnotetext{
${ }^{72}$ Tenże, Epistula 191 [Eustochio sophistae], PG 37, 313B, POK 15, 237.

${ }^{73}$ Tenże, Epistula 200 [Nemesio], PG 37, 328B, POK 15, 246.

${ }^{74}$ Tenże, Epistula 204 [Adelphio], PG 37, 337A-B, POK 15, 252-253.
} 
rodzaju powitaniem, gdyż otwiera treść listu. Ton tych słów zdradza wcześniejszy kontakt biskupa z młodzieńcem, a obecny list, pewnie odpowiedź Grzegorza jemu słaną, stanowi zweryfikowanie jego postępów. Następnie biskup wyjaśnia powód prowadzenia korespondencyjnego kierownictwa wobec niego: jest bowiem ośmielony rzadkimi cechami jego osobowości, dlatego chętnie go wspiera. Ostatni passus wskazuje na zamknięcie czynionych w tym liście zaleceń, istotnych dla osiągnięcia doskonałości przez adresata.

Kolejne listy adresowane do Adelfiusza przedstawiają dalszą historię wzajemnych kontaktów. Ostatecznie (początkowo przeszkadzała choroba płuc) Grzegorz spełnił obietnice zapowiedzianą listownie i odwiedził Adelfiusza w Nauiloi. Niestety, doznał rozczarowania, ponieważ Adelfiusz dał się ponieść urokom młodości. Biskup pełen żalu pisze do niego:

„Wstrząśnięty i ja tym przykładem, podjąłem się tego upomnienia. Nie wiem, co się z tobą stało! Co za zamroczenie w twej duszy! Dlaczego hańbisz swój ród? [...]. O wiele zaś straszniejsze, że dziewice, które albo twoi rodzice albo ty sam - jakeś wyznał - Bogu poświęciłeś, świętokradzko uprowadzasz, jedne już masz, innym wygrażasz, że je to samo czeka"75.

Cała treść listu jest rozbudowanym upomnieniem i wyliczeniem błędów moralnych popełnionych przez Adelfiusza. Na początku Grzegorz umieścił słowa wyrażające jego oburzenie i niedowierzanie. Następnie przechodzi do oceny czynów, jakich dopuścił się Adelfiusz, którymi zhańbił swój dom i rodzinę. Dla Grzegorza musiało to być przykre doświadczenie, pełne rozterek i bezsilności. Dlatego w zakończeniu listu dodał: „Zaniecham dalszego pisania, bo wiem, że jeśli cię nie pouczy bojaźń Boża, mało albo nic nie pomogą słowa"76. Grzegorz tym sposobem rezygnuje z własnych pomysłów na uratowanie sytuacji Adelfiusza, ale powierza ją Bogu.

Opisywana wyżej sprawa Sacerdosa dotykała w sposób bezpośredni także Teklę, która była jego siostrą. Zanim spór się zakończył, Sacerdos zmarł. W związku z tym Grzegorz wysyła do niej pocieszający list, który zawiera wiele wzniosłych myśli. Na ich zakończenie biskup wyznaje, także we własnym imieniu: „Błogosławmy przeto tę samą prawicę Pańską i bierzmy zrządzenia Jego wznioślej, niż tłum!" "77 Biskup daje tym samym świadectwo wiary w Bożą Opatrzność, do czego przekonuje również Teklę. Nad wszystkimi ludzkimi poczynaniami czuwa - jak się wyraził Grzegorz - „ta sama prawica Pańska”. W podobnym duchu został zredagowany drugi list do Tekli, w którym Grzegorz podobnie się wypowiada: „Dobrym więc dla nas jest lekarstwem pomnieć, gdy cierpimy, na Boga i nadzieje tamtego żywota"78. W tych słowach punkt ciężkości przesuwa się w kierunku życia wiecznego,

\footnotetext{
${ }^{75}$ Tenże, Epistula 206 [Adelphio], PG 37, 341A, POK 15, 254-255.

${ }^{76}$ Tamże, PG 37, 241C, POK 15, 255.

${ }^{77}$ Tenże, Epistula 222 [Theclae], PG 37, 363A, POK 15, 269.

${ }^{78}$ Tenże, Epistula 223 [Theclae], PG 37, 265A-B, POK 15, 271.
} 
to znaczy, aby życie doczesne złożyć w rękach Boga, a także trwać w nadziei na inne życie.

W innym liście zachętę ku dobremu Grzegorz połączył z życzeniami weselnymi, które otrzymał ojciec panny młodej:

„Jedną z tych pięknych rzeczy jest, by Chrystus był obecny na weselu - bo gdzie Chrystus, tam piękny ład - i by woda stała się winem, to jest, wszystko zamieniło się na lepsze"79.

Biskup w przekazywanych życzeniach wykorzystał biblijne wydarzenie z Kany Galilejskiej (tj. zamiana wody w wino), co miało w życiu nowożeńców symbolizować przemianę ich związku na coś lepszego. Grzegorz wymienił „piękny ład”, będący owocem tej przemiany. Zaznaczył jednak, że jest on możliwy tylko wówczas, gdy także Chrystus zostanie zaproszony do współudziału ${ }^{80}$.

Apogeum troski o duchowość chrześcijańską swoich korespondentów Grzegorz zamieścił w ostatnim liście swego zbioru. Kieruje go do Bazylissy, przypominając jej bardzo liczne zasady życia duchowego. Zanim Grzegorz przejdzie do wyliczenia przeróżnych wskazówek co do postępowania, uprzedza je słowami:

„nie zawaham się, ze względu na wspólną korzyść, spotęgować wedle sił twoją ochotność: nie przez dokładanie jakichś innych, cudzych wskazówek, lecz przez przypomnienie tego, o czym często mówiliśmy i w czym się zwyczajnie ćwiczysz" $"$.

Przytoczone słowa w sposób bezpośredni odkrywają aktywność Grzegorza na polu kierownictwa duchowego. Bazylissa jest tego przykładem. Często kontaktowała się ze swoim mistrzem, który podawał jej zalecenia dostosowane do jej struktury duchowej. Nie korzystał więc z „cudzych wskazówek”, ale potrafił wybrać te, które były odpowiednie do jej osobowości. Treść listu jest zatem krótkim traktatem na temat duchowości chrześcijańskiej, według której żył i postępował Nazjanzeńczyk, co wyrażają jego słowa: ,ze względu na wspólną korzyść”. Przypomnienie długiej listy wszelkich cnót ${ }^{82}$, które należało zdobyć, stało się także celem jego duchowych ćwiczeń.

3. Wobec krewnych. Dla Grzegorza więzy rodzinne odgrywały istotną rolę, co udowadniają listy adresowane także do krewnych. Nazjanzeńczyk podejmował w nich wątki, które pojawiały się w zależności od tego,

${ }^{79}$ Tenże, Epistula 232 [Diocli], PG 37, 376A, POK 15, 278.

${ }^{80} \mathrm{O}$ istocie małżeństwa i znaczeniu rodziny w oparciu o listy Grzegorza z Nazjanzu pisze C.N. Tsirplanis, Saint Gregory the Teologian on marriage and family, „Patristic and Byzantine Review" 4 (1985) 33-38.

${ }^{81}$ Gregorius Nazianzenus, Epistula 244 [Basilissae], PG 37, 385C, POK 15, 287.

${ }^{82}$ Por. tamże, PG 37, 385C-D oraz PG 37, 388A-B, POK 15, 287-288. 
co przydarzyło się poszczególnym osobom z jego rodziny. Zwracał w nich również uwagę na elementy duchowej doskonałości. Prawie cała treść bardzo krótkiego listu (dwa zdania) do Eulaliusza dotyczy właśnie tego tematu:

„Ty uprawiasz samotność i tak nieumiarkowane posty, ja milczenie. Udzielmy sobie nawzajem duchowych korzyści" ${ }^{33}$.

Przytoczone słowa to pierwsze zdanie listu. Zachęta do doskonałości polega na sugestii, aby nastąpiła wymiana duchowych korzyści wynikających z prowadzenia innych ćwiczeń duchowych: u biskupa - milczenia, a u adresata postu. Ponadto $\mathrm{w}$ tonie tej wypowiedzi wyczuwalna jest radość $\mathrm{z}$ tego, że Eulaliusz angażuje się w rozwój swej duchowości ${ }^{84}$.

Kolejny list Grzegorz skierował do swego kuzyna Amfilochiusza, który został wybrany na biskupa Ikonium. Zawiera wiele serdeczności, więzi kapłańskiej i refleksji teologicznych. Autor listu dziękuje za duchowe wsparcie:

„Ledwiem wytchnał po udrękach choroby, spieszę do ciebie, przyczyno mego uleczenia. Bo język kapłana, wyznający Panu, dźwiga chorujących"s5.

Nazjanzeńczyk dostrzega w swoim kuzynie dobroczyńcę: dzięki bowiem jego modlitwom i kapłańskiemu wstawiennictwu minęły udręki choroby. W następnych passusach listu prosi go o dalszą pomoc duchową za pośrednictwem mocy sakramentu Eucharystii. W ten sposób Grzegorz dał świadectwo swej wiary w moc Eucharystii, a także podkreślił otwartość i służebność Amfilochiusza. Doceniając jego doskonałość duchowa, prosi go w innym liście o rozstrzygnięcie sporu ${ }^{86}$.

Inna kwestia pojawiła się w liście do Walentyniana, krewnego, któremu Grzegorz w pewnym stopniu zarzuca zakłócenie spokoju, jakiego doznawał w swej posiadłości, Karbali. Walentynian wraz ze swą rodziną powziął plan wprowadzenia się do posiadłości, sąsiadującej z Karbalą. Grzegorz wyraża w liście różne swoje obawy z takiego sąsiedztwa, pisząc:

„Wszak was, gdy w tę ustroń przybywacie, i przyjmuję i witam serdecznie. [...] Przede wszystkim zaś owego się wystrzegajcie: nie tykajcie rzeczy poświęconych męczennikom, byście inaczej nie zaszkodzili i sobie i swoim, niszcząc tym przewrotnym najściem to, co tam jest" ${ }^{\text {"87 }}$.

We fragmencie listu poprzedzającym powyższe słowa Grzegorz nazywa decyzję Walentyniana względem siebie dosyć radykalnie: jest bowiem wypędzeniem, pojmowanym jako wypędzenie z dotychczasowej ciszy. Grzegorz stara

${ }^{83}$ Tenże, Epistula 111 [Eulalio], PG 37, 209A, POK 15, 157.

${ }^{84}$ Eulaliusz później zostanie biskupem Nazjanzu, jako następca Grzegorza, por. tenże, Epistula 158 [Eulalio], PG 37, 265, POK 15, 201.

${ }^{85}$ Tenże, Epistula 171 [Amphilochio], PG 37, 280C, POK 15, 211.

${ }^{86}$ Por. tenże, Epistula 184 [Amphilochio], PG 37, 302B-C, POK 15, 229.

${ }^{87}$ Tenże, Epistula 203 [Valentiniano], PG 37, 356B, POK 15, 251. 
się zrozumieć rodzinną sytuację swego krewnego, dlatego w dalszej części listu przyjmuje postawę otwartości, a nawet serdecznego powitania. Niemniej przekazuje listowne ostrzeżenie, by uszanowali miejsce poświęcone męczennikom, którym była kaplica znajdująca się w Arianzos ${ }^{88}$. Grzegorz w ostatnich latach życia troszczył się o kult męczenników, wygłaszał tam mowy i zapraszał swoich znajomych do odwiedzenia jej. Była więc dla niego miejscem świętym i pragnie, aby takim pozostała, mimo pojawienia się w jej sąsiedztwie nowych mieszkańców. Najprawdopodobniej biskup znał codzienne postępowanie swoich krewnych, dlatego ośmielił się uprzedzająco wysłać prośbę w sprawie dla niego ważnej.

Nieco inny wydźwięk posiada list do męża siostrzenicy, Meletjusza. Grzegorz przynagla adresata i siebie do wznowienia obyczajów rodzinnych:

„Gdzie nasze bratnie grono? Gdzie wspólne rozmowy i zebrania i owe słodkie i nieustające źródło, z któregośmy czerpali?"

Biskup czyni wyrzut Meletjuszowi i jednocześnie sobie, że zaniedbują familiarne relacje, które wcześniej wnosiły w ich życie tyle dobra. Jakość kontaktów rodzinnych została przez Grzegorza wyrażona kilkoma zwrotami: „bratnie grono”, „wspólne rozmowy i spotkania” oraz „słodkie i nieustające źródło". Świadczą one o pozytywnych stosunkach pomiędzy członkami rodziny, z której Grzegorz pochodził, a które przed końcem życia wspomina z nostalgią. Pragnie je wznowić i przywrócić jako trwałą wartość, służącą dla podtrzymywania więzów rodzinnych, choć z pewnością zakłada, że to może okazać się już nieosiągalne.

Lektura listów Grzegorza z Nazjanzu, napisanych po powrocie do rodzinnych stron, z perspektywy jego troski o doskonałość duchową bliskich mu osób pokazuje, że ilość wszelakich wskazówek, porad, przestróg, napomnień, zaleceń, przede wszystkim zachęt do prowadzenia życia prawdziwie chrześcijańskiego jest imponująca. Obok nich nie brakuje także licznych pochwał dotyczących posiadanych zalet ducha u jego adresatów. Niezależnie od tego, czy treść listu była kierowana do biskupa, prezbitera, diakona, mnicha, urzędnika wysoko postawionego, bliskiego mu przyjaciela, czy też członka rodziny, Grzegorz okazywał się z jednej strony doradca, bratnią duszą i kimś pełnym empatii, z drugiej jednak był wymagającym pasterzem, który pragnie dla nich szczęścia wynikającego z nabycia cnót ewangelicznych, a przede wszystkim umiejętności kroczenia drogą prowadzącą do życia wiecznego.

${ }^{88}$ Odniesienia do kaplicy męczenników mieszczą się w innych listach. Por. tenże, Epistula 98 i 122.

${ }^{89}$ Tenże, Epistula 240 [Meletio], PG 37, 384A, POK 15, 284. 
Takie podejście Nazjanzeńczyka było możliwe, ponieważ cieszył się dużym autorytetem zarówno w stolicy w czasie pełnienia swoich obowiązków pasterskich, jak i potem, przebywając w rodzinnych stronach. Zasadniczym powodem troski w sprawach duchowych była jego osobista duchowość i wrażliwość na wartości duchowe u innych. Analiza wielu wypowiedzi z jego korespondencji zdradza u niego ponadto znawstwo ludzkiej psychiki, jej niedomagań przy jednoczesnej możliwości doradzenia. Wnikanie w powikłane usposobienia ludzi należało bowiem do cech osobowości Grzegorza. Rozmaitość sytuacji, którym należało zaradzić, pokazuje umiejętności Grzegorza do rozpoznawania charakteru dusz ludzkich, określania ich jakości, a przede wszystkim wskazywania dróg poprawy lub też rozwijania posiadanych zalet. W sposób jednak bardzo ścisły wiązał przy tym życie ziemskie z życiem wiecznym.

Należy ponadto stwierdzić, że zalecenia i zachęty zapisane na kartach listów Grzegorza stanowią przykład jego stanowczego podejścia do spraw związanych $\mathrm{z}$ moralnością, a $\mathrm{w}$ dalszej konsekwencji także $\mathrm{z}$ duchowością chrześcijańską, której różne aspekty doskonale poznał i rozumiał. Tego typu aktywność Nazjanzeńczyka należy postrzegać w kategoriach kierownictwa duchowego pełnionego poprzez kontakt nie bezpośredni, ale listowny. Swą opieką duchową ogarniał także pogan, którym wskazywał na światłość, którą przyniósł Jezus Chrystus.

\section{RECOMMENDATIONS AND ENCOURAGEMENT TO PERFECT LIFE IN THE CORRESPONDENCE OF GREGORY OF NAZIANZUS}

\section{(Summary)}

The text of the article is an analysis of Gregory of Nazianzus' comments on Christian perfection. They were selected from his letters written in his family regions after returning from Constantinople, where he occupied for two years the position in the episcopal capital. It was a period of almost ten years of his life, until his death in 390, in which he contacted many people mainly through letters, because weak health prevented him from traveling frequently. The analysis of the letters showed that the threads containing recommendations, warnings, cautions, and encouragements were numerous in them. They have been divided in three categories of addresses, i.e. clergy and monks, lay people and family members. Depending on the situation, the needs of addressees, their spiritual disabilities, or even their progress on the path to perfect living, Gregory demonstrated the skills of good spiritual help. His sensitivity to human problems, related to everyday life, triggered his concern for their proper evaluation. All human activity was perceived by him in terms of God's providence and eternal life. He considered the abidance of Christian principles to be the duty of every follower of Jesus Christ, so he had made efforts to ensure that the recipients of his letters were not indifferent to spiritual values. 
Key words: Gregory of Nazianzus, correspondence, Christian spirituality, encouragement to perfection.

Słowa kluczowe: Grzegorz z Nazjanzu, korespondencja, duchowość chrześcijańska, zachęta do doskonałości.

\section{BIBLIOGRAFIA}

\section{Źródła}

Gregorius Nazianzenus, Epistulae, PG 37, 21-388, thum J. Stahr: Grzegorz z Nazjanzu, Listy, POK 15, Poznań 1933 [reprint 2005].

\section{Opracowania}

Amata B., „Decor”, ,,mediocritas”, ,, consolatio” nelle lettere di S. Gregorio Nazianzeno, w: Culture e Lingue Classiche 3. Terzo Convegno di aggiornamento e didattica, ed. B. Amata, Roma 1993, 965-985.

BARResi S., La vita e l'opera di Gregorio di Nazianzeno attraverso l'epistolario, Catania 1955.

Cataldo A., Come l'oro nel crogiuolo (Greg. Naz. Ep. 214 e Sap. 3,5,6), „Quaderni dell'Istituto di Lingue e letterature Classiche" 2 (1983) 17-27.

Cataldo A., Virtú e ricerca di Dio nell'epistolario di S. Gregorio di Nazianzo, „Sileno” 5-6 (1979-1980) 183-207.

Crimi C.U., Allusioni e citatzioni di testi teatrali nell 'Epistolario di Gregorio Nazianzeno, Catania 1981.

Gallay P., Saint Grégoire de Nazianze dans sa correspondance, „Bulletin des Facultés Catholiques de Lyon" 43 (1967) 5-25.

Longosz S., Widowiska teatralne zagrożeniem dla życia rodzinnego wedlug św. Jana Chryzostoma, w: Chrześcijanie a życie publiczne w Cesarstwie Rzymskim III-IV w., red. J. Śrutwa, Lublin 1988, 135-198.

Malunowiczówna L., Listy konsolacyjne i mowy żałobne Grzegorza z Nazjanzu, RTK 25 (1978) z. 4, 173-201.

Mitchell J.F., Consolatory lettres in Basil and Gregory Nazianzen, „Hermes” 96 (1968) 299-318.

Pappalardo M., Wielki Post i Wielkanoc z Ojcami Kościoła, thum. M. Dobosz, Warszawa 2010.

Simonetti M., La crisi ariana nel IV secolo, Roma 1975.

Szymusiak J.M., Grzegorz Teolog. Uźródet chrześcijańskiej myśli IV wieku, Poznań 1965, $142-143$.

ŚRUTWA J., Widowiska epoki klasycznej w ocenie Kościoła afrykańskiego II-V w., RTK 27 (1980) z. 4, 43-56.

Tsirplanis C.N., Saint Gregory the Teologian on marriage and family, „Patristic and Byzantine Review" 4 (1985) 33-38.

Widok N., Postawa Grzegorza z Nazjanzu wobec świeckich w świetle jego listów protekcyjnych, VoxP 22 (2002) t. 42-43, 187-207.

Widok N., Refleksje o sobie samym w korespondencji starego Grzegorza z Nazjanzu, VoxP 31 (2011) t. 56, 349-370.

WIDoK N., Troska o sprawy Kościoła w korespondencji ostatniej dekady życia Grzegorza z Nazjanzu, VoxP 36 (2016) t. 65, 697-716. 
